\title{
Angiotensin-converting enzyme insertion/deletion polymorphism, 24-h blood pressure profile and left ventricular hypertrophy in hypertensive individuals: a cross-sectional study
}

Luciana Neves Cosenso-Martin", Renan Oliveira Vaz-de-Melo1, Luana Rocco Pereira1, Cláudia Bernardi Cesarino' , Juan Carlos Yugar-Toledo ${ }^{1}$, José Paulo Cipullo ${ }^{1}$, Marcela Augusta de Souza Pinhel², Dorotéia Rossi Silva Souza ${ }^{2}$ and José Fernando Vilela-Martin ${ }^{1 *}$

\begin{abstract}
Background: The absence of nocturnal blood pressure dipping (ND) identified by 24-h ambulatory blood pressure monitoring (ABPM) correlates with a worse cardiovascular prognosis. The renin-angiotensin system influences blood pressure levels and the occurrence of target organ damage (TOD). Thus, the aim of this study was to correlate the angiotensin-converting enzyme gene (ACE) insertion/deletion (I/D) polymorphism with the 24-h blood pressure profile and TOD in hypertensive individuals.
\end{abstract}

Methods: 155 non-diabetic hypertensive individuals on antihypertensive treatment underwent ABPM. Peripheral blood samples were drawn for biochemistry and genetic analysis of the ACE I/D polymorphism by polymerase chain reaction. ND was defined as $\geq 10 \%$ differences in the mean systolic blood pressure (BP) during wakefulness and sleep.

Results: There were no differences in clinical or biochemical variables or TOD in respect to ND status, except for higher BP levels during sleep $(p<0.001)$ in non-dippers. There was significant difference in the prevalence of left ventricular hypertrophy (LVH) between ACE genotypes (II: $13.0 \%$; ID: $34.1 \%$; DD: $46.5 \% ; p$ value $=0.024$ ) with an increased risk in carriers of the DD genotype $(\mathrm{OR}=5.80$; IC $95 \% 1.50-22.44 ; p$ value $=0.011)$. Carriers of the $\mathrm{D}$ allele had higher systolic BP during wakefulness and by ABPM $(p<0.05)$, higher left ventricular mass $(117.3 \pm 50.0$ vs. $100.3 \pm 25.7 ; p$ value $=0.017)$ and higher prevalence of $\mathrm{LVH}(37.4$ vs. $12.5 \%$; OR $=4.14 ; 95 \%$ IC: $1.17-14.65 ; p$ value $=0.028$, compared to the II genotype.

Conclusions: The DD genotype is associated with a higher prevalence of $\mathrm{LVH}$. The presence of the $\mathrm{D}$ allele appears to be associated with higher mean 24-h and wake systolic BP measured by ABPM in hypertensive patients under antihypertensive treatment.

Keywords: Angiotensin-converting enzyme, Hypertension, Left ventricular hypertrophy, Nocturnal dipping, Polymorphism, Target organ damage

\footnotetext{
*Correspondence: vilelamartin@uol.com.br

${ }^{1}$ Hypertension Clinic, Internal Medicine Department, State Medical School in São José do Rio Preto (FAMERP) and Hospital de Base, Ave Brig.

Faria Lima 5416, São José do Rio Preto, São Paulo 15090-000, Brazil

Full list of author information is available at the end of the article
} 


\section{Background}

Hypertension (HT) is a highly prevalent disease associated with increased risk of target organ damage (TOD), including myocardial infarction, stroke and left ventricular hypertrophy (LVH). Changes in blood pressure are influenced by daily activities and interactions with neurohumoral, behavioral and environmental factors. Under physiological conditions, there is a drop in the blood pressure (BP) between wakefulness and sleep, a phenomenon known as nocturnal blood pressure dipping (ND). The absence of ND is associated with TOD and higher mortality [1-4].

Due to the multifactorial etiology of HT, many researchers are studying the association between genetic polymorphisms and HT and its complications. This research studied the angiotensin-converting enzyme (ACE) gene insertion/deletion (I/D) polymorphism, which is characterized by the presence (insertion) or absence (deletion) of an Alu repetitive sequence of 287 base pairs (bp) in intron 16 of the ACE gene [5]. The variability in plasma ACE levels is directly related to the I/D polymorphism; the I allele is associated with a reduced level of this enzyme and lower concentrations of angiotensin II in tissues [5], a condition that apparently protects against TOD.

The ACE I/D polymorphism is linked to risk for myocardial infarction and cardiovascular events [6-9], LVH [10-12], microalbuminuria [11, 13, 14], thoracic aortic aneurysm in patients with bicuspid or tricuspid aortic valves [15], pregnancy hypertensive disorders [16, 17], and hypertensive emergency [18]. Moreover, this polymorphism is related to inter-individual differences in $\mathrm{BP}$ response, for example, a low dose of the hydrochlorothiazide diuretic produced greater BP reductions in men with the DD genotype and women with the II genotype [19]. Therefore, this polymorphism may also have a role in the genesis of TOD, which is commonly found in hypertensive individuals. Recently, a meta-analysis of 44 articles involving 12,616 subjects, demonstrated the contribution of the I/D polymorphism to susceptibility for LVH [20].

The findings reported in the literature in respect to the relationship of this polymorphism with BP levels and TOD are controversial [14, 21-31]. Thus, this study aimed to characterize the anthropometric, biochemical, and echocardiographic data and blood pressure profile of non-diabetic hypertensive individuals and to investigate the influence of the ACE I/D polymorphism on 24-h BP levels and on TOD.

\section{Methods}

This project was approved by the Research Ethics Committee of the State Medical School in São José do Rio
Preto (no. 169/2008). All participants were informed about the purpose of the work and gave their written informed consent before participating in the research. This was a cross-sectional study, which enrolled 155 hypertensive individuals followed-up at a university hospital outpatient clinic. The exclusion criteria were age under 40 years, history of valvular disease, systolic/ diastolic dysfunction, diabetes mellitus (DM), body mass index (BMI) $\geq 35 \mathrm{~kg} / \mathrm{m}^{2}$, creatinine clearance $<30 \mathrm{~mL} /$ $\mathrm{min} / \mathrm{m}^{2}$, and secondary hypertension.

An investigative protocol was used to collect information on age, gender, medicines taken, and comorbidities. Data regarding DM, strokes, MI, and dyslipidemia (DLP) were used to assess comorbidities. Patients who had presented with two or more fasting glycemia levels $\geq 126 \mathrm{mg} / \mathrm{dL}$ or altered oral glucose tolerance test $(\geq 200 \mathrm{mg} / \mathrm{dL}$ ) were excluded [32]. History of strokes was based on clinical history, medical records, and the presence of sequels. The diagnosis of MI was based on clinical history and confirmed by an analysis of medical records that described enzymatic alterations (troponin and CK-MB), and electrocardiographic alterations suggestive of coronary ischemia and treatment. DLP was identified by total cholesterol (TC), high-density lipoprotein cholesterol fraction (HDL-c) and triglycerides (TG) levels after $12 \mathrm{~h}$ of fasting [33]. The following reference values were adopted: TC $<200 \mathrm{mg} / \mathrm{dL}$, HDL-c $>40 \mathrm{mg} / \mathrm{dL}$, low-density lipoprotein cholesterol fraction (LDL-c) $<130 \mathrm{mg} / \mathrm{dL}$ and TG $<150 \mathrm{mg} / \mathrm{dL}$. The LDL-c fraction was calculated using the formula: LDL-c $=$ TC - HDL-c - TG/5 (for TG $<400 \mathrm{mg} / \mathrm{dL}$ ) [34]. DLP was defined for individuals with alterations in the aforementioned parameters and those who were under treatment with HMG-CoA reductase inhibitors or other hypolipemic drugs.

Weight and height were measured and BMI was calculated using the formula: $\mathrm{BMI}=$ weight $(\mathrm{kg}) /$ height $(\mathrm{m})^{2}$. Besides stroke and MI, TOD was also considered as the presence of microalbuminuria and left ventricular hypertrophy (LVH). Microalbuminuria was characterized as the average of two 24-h urinary albumin excretion rates $\geq 20 \mu \mathrm{g} / \mathrm{min}$.

\section{Echocardiographic analysis}

All echocardiographic examinations were performed by the same experienced echocardiographer. M-Mode echocardiograms were performed under cross-sectional control, with the patient in partial left decubitus position, using an Philips HD15 PureWave ultrasound system and S5-2 Broadband Sector Array Transducer (Andover, MA 01810-1099 -USA) with 2.5- to 3.5-MHz mechanical transducers. Left ventricular (LV) dimensions and mass were assessed from 2D-guided M-mode tracings according to American Society of Echocardiography (ASE) 
recommendations. M-mode measurements were averaged from three cycles. LV end-systolic, end-diastolic, and stroke volumes were calculated. Ejection fraction was calculated from derived volumes with computed based on the "cubed" or "Teichholtz" equations, but only in the absence of asynergy. 2-D method of Simpson calculated was performed in distorted ventricles [35]. To evaluate the segmental LV function, the ASE recommends adopt 17-segment model scored as 1: normal, 2: hypokinetic, 3: akinetic, 4: dyskinetic, and 5: aneurysmal (diastolically deformed). The ASE also recommends that wall motion be judged by segmental thickening in addition to endocardial motion.

The ASE-recommended formula for estimation of LV mass from LV linear dimensions was performed to define LVH. Left ventricular hypertrophy was defined as left ventricular mass index (LVMI) $>115 \mathrm{~g} / \mathrm{m}^{2}$ in men and $>95 \mathrm{~g} / \mathrm{m}^{2}$ in women [35]. Relative wall thickness was calculated as twice the posterior wall in diastole divided by internal diastolic diameter and was used to estimate the LV geometry concentric (RWT $\geq 0.42$ ) or eccentric (RWT $\leq 0.42$ ) hypertrophy [36]. The diastolic dysfunction was evaluated by the ASE and the European Association of Echocardiography (EAE) recommendations. They apply an algorithm that takes into account not only the $\mathrm{E} / \mathrm{A}$ ratio, but the deceleration time of the $\mathrm{E}$ wave, the early and late velocities of the mitral annulus measured by tissue Doppler ( $\mathrm{e}^{\prime}$ and $\left.\mathrm{a}^{\prime}\right)$, the left atrial volume, the pattern of pulmonary vein flow, and the duration of reversed flow into the pulmonary veins during atrial contraction. The algorithm includes the parameter E/e and also investigates the color M-mode velocity of propagation of the mitral inflow toward the apex. A rapid velocity coincides with normal diastolic function, whereas a slower velocity indicates delayed relaxation [37].

\section{Ambulatory blood pressure monitoring}

BP levels were obtained by ambulatory blood pressure monitoring (ABPM) taking into account the average BP over a 24-h period and differences in the mean awake and sleep BP (presence or absence of ND). ABPM was performed using the Spacelabs 90207 equipment. The equipment was fitted during the daytime and the patient remained with the unit for a period of $24 \mathrm{~h}$. The monitoring process was carried out without patients changing their normal daily activities. The device was programmed to record BP levels at 15-min intervals during daytime, and 20-min intervals at night. All participants were instructed to make notes on their daily activities including meal times, bedtime, and the timing of medications and symptoms. Thus, periods of wakefulness and sleep were defined based on the time recorded by patients in their diaries. ND was defined as $\geq 10 \%$ drop in systolic
BP from wakefulness to sleep [38]. Individuals were classified as dippers (with ND) or non-dippers (without ND). In addition, patients were classified according to the ACE I/D genotypes. Subsequently, patients were grouped as carriers of the D allele (ID and DD genotypes) and compared to those homozygous for the I allele.

\section{Genetic analysis}

Peripheral blood was drawn for the extraction of DNA. The analysis of the genetic variants of the ACE gene was performed by extracting genomic DNA from leukocytes [39], with DNA amplification by conventional polymerase chain reaction (PCR) [40]. The amplification of the polymorphic segment to analyze the ACE I/D polymorphism was performed by initial denaturation with 30 cycles at $94{ }^{\circ} \mathrm{C}$ for $1 \mathrm{~min}, 58{ }^{\circ} \mathrm{C}$ for $1 \mathrm{~min}, 72{ }^{\circ} \mathrm{C}$ for $1.5 \mathrm{~min}$, and a final extension of $72{ }^{\circ} \mathrm{C}$ for $10 \mathrm{~min}$ [40]. Since the amplification of the I allele (490 bp) is less efficient than that of the D allele $(190 \mathrm{bp})$, the specificity of the DD genotyping was increased by amplifying all DD samples using a pair of specific primers for the insertion sequence, with the presence of a DNA fragment of $335 \mathrm{bp}$ confirming the ID genotype [40]. In this case, PCR was performed with 35 cycles at $94{ }^{\circ} \mathrm{C}$ for $30 \mathrm{~s}, 69^{\circ} \mathrm{C}$ for $45 \mathrm{~s}$, $72{ }^{\circ} \mathrm{C}$ for $2 \mathrm{~min}$, and a final extension of $72{ }^{\circ} \mathrm{C}$ for $7 \mathrm{~min}$. The amplification products were subjected to electrophoresis on 1 and $1.8 \%$ agarose gel for samples amplified by the first reaction, and the second reaction, respectively, followed by staining using ethidium bromide and visualization under ultraviolet light.

\section{Statistical analysis}

Descriptive analysis was conducted for the quantitative variables with the presentation of mean values and standard deviations. The Student $t$ test and ANOVA were used to analyze quantitative variables and the $\chi^{2}$ test for qualitative variables. The allelic and genotypic frequencies were compared between the groups using the $\chi^{2}$ test. The influence of alleles and genotypes on 24-h BP and TOD was detected by calculating cross-products [Odds ratio (OR)] with a $95 \%$ confidence interval (95\% CI). All statistical analyses were performed using the Minitab 15.0 computer program. An alpha error greater than $5 \%(p$ value $<0.05$ ) was considered statistically significant.

\section{Results}

The anthropometric, biochemical, and echocardiographic data and blood pressure profile of the sample are presented in Table 1 . The mean time of HT (16.0 \pm 10.1 years), BP levels above the recommended range, and increased values of BMI $\left(28.8 \pm 4.9 \mathrm{~kg} / \mathrm{m}^{2}\right)$ and microalbuminuria (58.1\%) stand out in this sample. On comparing individuals with and without ND, there 
Table 1 Anthropometric, biochemical, and echocardiographic variables, blood pressure profile and drugs used by hypertensive patients

\begin{tabular}{|c|c|}
\hline Variable & Sample $(n=155)$ \\
\hline Age (years) & $63.2 \pm 11.4$ \\
\hline Gender (male/female) & $66 / 89$ \\
\hline Duration of hypertension (years) & $16.0 \pm 10.1$ \\
\hline $\mathrm{BMI}\left(\mathrm{kg} / \mathrm{m}^{2}\right)$ & $28.8 \pm 4.9$ \\
\hline Smoker, $n(\%)$ & $16(10.3)$ \\
\hline History of stroke, $n(\%)$ & $35(22.6)$ \\
\hline History of myocardial infarction, $n(\%)$ & $7(4.5)$ \\
\hline $\mathrm{LVH}, n(\%)$ & $52(33.5)$ \\
\hline Microalbuminuria, $n(\%)$ & $90(58.1)$ \\
\hline \multicolumn{2}{|l|}{ Drugs } \\
\hline Hypolipemiant, $n(\%)$ & $71(45.8)$ \\
\hline Aspirin, $n(\%)$ & $59(38.1)$ \\
\hline Diuretic, $n(\%)$ & $129(83.2)$ \\
\hline ACE inhibitor, $n(\%)$ & $103(66.5)$ \\
\hline Angiotensin II receptor antagonist, $n(\%)$ & $22(14.2)$ \\
\hline Calcium channel blocker, $n(\%)$ & $65(41.9)$ \\
\hline Beta-blocker, $n(\%)$ & $46(29.7)$ \\
\hline \multicolumn{2}{|l|}{ Blood pressure levels } \\
\hline 24-h SBP (mmHg) & $135.2 \pm 17.4$ \\
\hline 24-h DBP (mmHg) & $81.7 \pm 11.0$ \\
\hline Daytime SBP (mmHg) & $137.4 \pm 17.6$ \\
\hline Daytime DBP (mmHg) & $83.7 \pm 11.8$ \\
\hline Nighttime SBP (mmHg) & $129.0 \pm 19.2$ \\
\hline Nighttime DBP (mmHg) & $75.2 \pm 11.8$ \\
\hline SBP dipping (\%) & $5.8 \pm 8.3$ \\
\hline SBP dipping (\%) & $10.0 \pm 9.1$ \\
\hline \multicolumn{2}{|l|}{ Echocardiographic profile } \\
\hline Septal thickness (mm) & $10.1 \pm 1.7$ \\
\hline Wall thickness (mm) & $9.8 \pm 2.9$ \\
\hline LV mass (g) & $203.2 \pm 83.4$ \\
\hline LV mass index $\left(\mathrm{g} / \mathrm{m}^{2}\right)$ & $114.7 \pm 47.4$ \\
\hline \multicolumn{2}{|l|}{ Biochemical profile } \\
\hline Fasting glycemia (mg/dL) & $96.6 \pm 15.6$ \\
\hline HDL-cholesterol (mg/dL) & $56.8 \pm 16.1$ \\
\hline LDL-cholesterol (mg/dL) & $116.2 \pm 88.2$ \\
\hline Total cholesterol (mg/dL) & $187.3 \pm 35.8$ \\
\hline Triglycerides (mg/dL) & $133.5 \pm 78.2$ \\
\hline Creatinine $(\mathrm{mg} / \mathrm{dL})$ & $1.5 \pm 1.7$ \\
\hline Microalbuminuria ( $\mu \mathrm{g} / \mathrm{min})$ & $33.6 \pm 46.3$ \\
\hline
\end{tabular}

$B M I$ body mass index, $L V H$ left ventricular hypertrophy, $A C E$ angiotensinconverting enzyme, $D B P$ diastolic blood pressure, $S B P$ systolic blood pressure, $L V$ left ventricle

were no differences between clinical, and biochemical variables or TOD except for lower BP levels during sleep $(p<0.001)$ in patients with ND (Table 2). There was not systolic and diastolic ventricular dysfunction and neither significant areas of infarction scars in the evaluated sample.

When grouped according to the genotype of the ACE I/D polymorphism, the groups did not significantly differ in respect to mean age, gender, BMI and duration of HT. There were no statistically significant differences between the three genotypes (II, ID, and DD) and mean 24-h BP by ABPM (Table 3). However, there was a significant difference in the prevalence of LVH between the ACE genotypes (II: $13.0 \%$; ID: $34.1 \%$; DD: $46.5 \%$; $p$ value $=0.024$ ). By logistic regression (Table 4), carriers of the DD genotype had higher risk of $\mathrm{LVH}$ compared to those with the II genotype (OR: $5.8 ; 95 \%$ CI 1.50-22.44; $p$ value $=0.011$ ). There was no significant difference between genotypes in respect to the other TOD investigated in this study.

Carriers of the D allele (ID and DD genotypes) had higher awake systolic BP and mean 24-h BP compared to those with the II genotype ( $p$ value $=0.036$ and $p$ value $=0.042$, respectively) (Table 3 ) although there were no statistically significant differences between the three genotypes. Moreover, carriers of the D allele also had higher left ventricular mass $(209.3 \pm 87.1$ vs. $170.1 \pm 48.0 \mathrm{~g} ; p$ value $=0.003)$, left ventricular mass index $\left(117.3 \pm 50.0\right.$ vs. $100.3 \pm 25.7 \mathrm{~g} / \mathrm{m}^{2} ; p$ value $=0.017)$ and, consequently, higher prevalence of LVH (37.4 vs. $12.5 \%$; $p$ value $=0.019)$ than individuals with the II genotype. By logistic regression, D allele carriers had a three times higher risk of LVH than those with the II genotype $(\mathrm{OR}=4.14 ; 95 \%$ CI $1.17-14.65 ; p$ value $=0.028)$ (Table 4$)$. The allelic and genotypic distributions of the population were in balance according to the Hardy-Weinberg equilibrium $\left(\chi^{2}=3.11 ; p>0.05\right)$.

\section{Discussion}

This study demonstrates an association between the $\mathrm{D}$ allele of the ACE I/D polymorphism and increased BP, and a correlation of the DD genotype with higher prevalence of LVH in non-diabetic hypertensive patients who despite antihypertensive treatment have poorly controlled BP.

Recently, there has been growing interest in association studies on the I/D polymorphism and ACE plasma levels and, consequently, on angiotensin II concentrations. However, results of studies on this relationship in hypertensive patients are controversial. Thus, while some casecontrol studies did not confirm any association between the I/D polymorphism and HT [21, 23, 24, 27, 41], others reported a higher frequency of the $\mathrm{D}$ allele $[28,31]$ and DD genotype in subjects with HT [22, 28-30]. In these cases, it is possible that the profile of the sample regarding age, gender and associated diseases may have influenced the distribution of ACE genetic variants. In 
Table 2 Studied variables and genotype distribution according to the nocturnal dipping

\begin{tabular}{|c|c|c|c|}
\hline Variable & Dippers $(n=50)$ & Non-dippers $(n=105)$ & $p$ value \\
\hline Age (years) & $62.8 \pm 12.0$ & $63.5 \pm 11.1$ & NS \\
\hline Gender (Male/Female) & $22 / 28$ & $44 / 61$ & NS \\
\hline Duration of hypertension (years) & $14.7 \pm 11.1$ & $16.6 \pm 9.6$ & NS \\
\hline BMI $\left(\mathrm{kg} / \mathrm{m}^{2}\right)$ & $28.3 \pm 4.8$ & $29.0 \pm 5.0$ & NS \\
\hline Smoker, $n(\%)$ & $6(12.0)$ & $10(9.5)$ & NS \\
\hline History of stroke, $n(\%)$ & $12(24.0)$ & $23(21.9)$ & NS \\
\hline History of myocardial infarction, $n(\%)$ & $1(2.0)$ & $6(5.7)$ & NS \\
\hline $\mathrm{LVH}, n(\%)$ & $16(34.0)$ & $36(34.6)$ & NS \\
\hline Microalbuminuria, $n(\%)$ & $26(52.0)$ & $64(60.9)$ & NS \\
\hline \multicolumn{4}{|l|}{ Drugs } \\
\hline Hypolipemiant, $n(\%)$ & $18(36.0)$ & $53(50.5)$ & NS \\
\hline Aspirin, $n(\%)$ & $15(30.0)$ & $44(41.9)$ & NS \\
\hline Diuretic, $n(\%)$ & $44(88.0)$ & $85(80.9)$ & NS \\
\hline ACE inhibitor, $n(\%)$ & $31(62.0)$ & $72(68.6)$ & NS \\
\hline Angiotensin II receptor antagonist, $n(\%)$ & $7(14.0)$ & $15(14.3)$ & NS \\
\hline Calcium channel blocker, $n$ (\%) & $24(48.0)$ & $41(39.0)$ & NS \\
\hline Beta-blocker, n (\%) & $11(22.0)$ & $35(33.3)$ & NS \\
\hline \multicolumn{4}{|l|}{ Blood pressure levels } \\
\hline 24-h SBP (mmHg) & $134.6 \pm 19.0$ & $135.6 \pm 16.6$ & NS \\
\hline 24-h DBP (mmHg) & $81.7 \pm 9.9$ & $81.7 \pm 11.6$ & NS \\
\hline Daytime SBP (mmHg) & $140.1 \pm 19.6$ & $136.1 \pm 16.6$ & NS \\
\hline Daytime DBP (mmHg) & $85.8 \pm 10.4$ & $82.7 \pm 12.3$ & NS \\
\hline Nighttime SBP (mmHg) & $118.7 \pm 16.7$ & $133.9 \pm 18.4$ & $<0.001$ \\
\hline Nighttime DBP (mmHg) & $69.3 \pm 9.2$ & $78.0 \pm 11.9$ & $<0.001$ \\
\hline SBP dipping (\%) & $15.1 \pm 4.6$ & $1.4 \pm 5.6$ & $<0.001$ \\
\hline SBP dipping (\%) & $19.0 \pm 5.7$ & $5.6 \pm 7.0$ & $<0.001$ \\
\hline \multicolumn{4}{|l|}{ Echocardiographic profile } \\
\hline Septal thickness (mm) & $10.1 \pm 1.6$ & $10.1 \pm 1.8$ & NS \\
\hline Wall thickness (mm) & $9.8 \pm 1.5$ & $9.9 \pm 3.4$ & NS \\
\hline LV mass (g) & $200.0 \pm 64.4$ & $204.8 \pm 91.3$ & NS \\
\hline LV mass index $\left(\mathrm{g} / \mathrm{m}^{2}\right)$ & $112.8 \pm 31.8$ & $115.6 \pm 53.1$ & NS \\
\hline \multicolumn{4}{|l|}{ Biochemical profile } \\
\hline Fasting glycemia (mg/dL) & $95.6 \pm 18.9$ & $97.1 \pm 13.8$ & NS \\
\hline HDL-cholesterol (mg/dL) & $56.7 \pm 15.2$ & $56.8 \pm 16.6$ & NS \\
\hline LDL-cholesterol (mg/dL) & $110.8 \pm 22.7$ & $109.2 \pm 31.6$ & NS \\
\hline Total cholesterol (mg/dL) & $193.6 \pm 28.4$ & $184.3 \pm 38.6$ & NS \\
\hline Triglycerides (mg/dL) & $138.8 \pm 71.6$ & $130.9 \pm 81.4$ & NS \\
\hline Creatinine (mg/dL) & $1.2 \pm 0.3$ & $1.3 \pm 1.1$ & NS \\
\hline Microalbuminuria ( $\mu \mathrm{g} / \mathrm{min})$ & $38.2 \pm 59.1$ & $31.6 \pm 39.7$ & NS \\
\hline \multicolumn{4}{|l|}{ Genotype } \\
\hline$\|, \mathrm{n}(\%)$ & $8(16.0)$ & $16(15.2)$ & NS \\
\hline $\mathrm{ID}, n(\%)$ & $25(50.0)$ & $62(59.0)$ & \\
\hline $\mathrm{DD}, n(\%)$ & $17(34.0)$ & $27(25.7)$ & \\
\hline \multicolumn{4}{|l|}{ Genotype combination } \\
\hline$\|, n(\%)$ & $8(16)$ & $16(15.3)$ & NS \\
\hline$D_{-}, n(\%)$ & $42(84)$ & $89(84.7)$ & \\
\hline
\end{tabular}

$B M I$ body mass index, $L V H$ left ventricular hypertrophy, $A C E$ angiotensin-converting enzyme, $D B P$ diastolic blood pressure, $S B P$ systolic blood pressure, $L V$ left ventricle, NS non-significant $(p>0.05)$ 
Table 3 Distribution of studied variables according to the genotypes of the ACE I/D polymorphism

\begin{tabular}{|c|c|c|c|c|c|c|}
\hline Variables & II $(n=24)^{a}$ & $\mathrm{ID}(n=87)^{\mathrm{b}}$ & $\mathrm{DD}(n=44)^{\mathrm{c}}$ & $p$ value $^{\mathrm{a} \times \mathrm{b} \times \mathrm{c}}$ & $\begin{array}{l}D D+I D \\
(n=131)^{d}\end{array}$ & $\begin{array}{l}p \\
\text { value }^{a \times d}\end{array}$ \\
\hline Age (years) & $61.7 \pm 11.9$ & $63.1 \pm 10.6$ & $64.3 \pm 12.6$ & NS & $63.5 \pm 11.3$ & NS \\
\hline Gender (male/female) & $8 / 16$ & $41 / 46$ & $17 / 27$ & NS & $58 / 73$ & NS \\
\hline Duration of hypertension (years) & $16.9 \pm 9.9$ & $15.9 \pm 10.0$ & $15.7 \pm 10.6$ & NS & $15.8 \pm 10.2$ & NS \\
\hline $\mathrm{BMI}\left(\mathrm{kg} / \mathrm{m}^{2}\right)$ & $27.8 \pm 4.0$ & $29.1 \pm 4.7$ & $28.8 \pm 5.7$ & NS & $29.0 \pm 5.1$ & NS \\
\hline History of stroke, $n(\%)$ & $9(37.5)$ & $17(19.5)$ & $9(20.5)$ & NS & $26(19.8)$ & NS \\
\hline History of myocardial infarction, $n(\%)$ & $0(0.0)$ & $5(5.8)$ & $2(4.5)$ & NS & $7(5.3)$ & NS \\
\hline $\mathrm{LVH}, n(\%)$ & $3(13.0)$ & $29(34.1)$ & $20(46.5)$ & 0.024 & $49(37.4)$ & 0.019 \\
\hline Microalbuminuria, $n(\%)$ & $14(58.3)$ & $54(62.0)$ & $22(50.0)$ & NS & $76(58.0)$ & NS \\
\hline Albuminuria ( $\mu \mathrm{g} / \mathrm{min})$ & $30.9 \pm 29.8$ & $27.7 \pm 24.9$ & $46.3 \pm 75.0$ & NS & $34.1 \pm 48.9$ & NS \\
\hline \multicolumn{7}{|l|}{ Drugs } \\
\hline Hypolipemiant, n (\%) & $10(41.7)$ & $37(42.5)$ & $24(54.5)$ & NS & $61(46.6)$ & NS \\
\hline Aspirin, $n(\%)$ & $9(37.5)$ & $33(37.9)$ & 17 (38.6) & NS & $50(38.2)$ & NS \\
\hline Diuretic, n (\%) & $21(87.5)$ & $71(82.6)$ & $37(84.1)$ & NS & $108(83.1)$ & NS \\
\hline ACE inhibitor, $n(\%)$ & $17(70.8)$ & $58(66.7)$ & $28(63.6)$ & NS & $86(65.7)$ & NS \\
\hline Angiotensin II receptor antagonist, $n(\%)$ & $2(8.3)$ & $17(19.5)$ & $3(6.8)$ & NS & $20(15.3)$ & NS \\
\hline Calcium channel blocker, $n(\%)$ & $10(41.7)$ & $36(41.4)$ & $19(43.2)$ & NS & $55(42.0)$ & NS \\
\hline Beta-blocker, n (\%) & $8(33.3)$ & $28(32.2)$ & $10(22.7)$ & NS & $38(29.0)$ & NS \\
\hline \multicolumn{7}{|l|}{ Blood pressure levels } \\
\hline 24-h SBP (mmHg) & $129.9 \pm 12.6$ & $134.8 \pm 16.7$ & $139.1 \pm 20.1$ & NS & $136.2 \pm 18.0$ & 0.042 \\
\hline 24-h DBP (mmHg) & $79.3 \pm 5.9$ & $81.7 \pm 10.5$ & $82.9 \pm 13.7$ & NS & $82.1 \pm 11.7$ & NS \\
\hline Daytime SBP (mmHg) & $131.8 \pm 12.7$ & $136.5 \pm 17.1$ & $142.2 \pm 19.9$ & NS & $138.4 \pm 18.2$ & 0.036 \\
\hline Daytime DBP (mmHg) & $80.0 \pm 9.4$ & $84.0 \pm 11.0$ & $85.2 \pm 13.9$ & NS & $84.4 \pm 12.0$ & NS \\
\hline Nighttime SBP (mmHg) & $123.8 \pm 15.4$ & $129.2 \pm 19.0$ & $131.4 \pm 21.2$ & NS & $130.0 \pm 19.7$ & NS \\
\hline Nighttime DBP (mmHg) & $73.2 \pm 7.0$ & $75.5 \pm 11.6$ & $75.6 \pm 14.2$ & NS & $75.6 \pm 12.5$ & NS \\
\hline SBP dipping (\%) & $5.5 \pm 7.9$ & $5.3 \pm 8.0$ & $6.9 \pm 9.0$ & NS & $5.9 \pm 8.4$ & NS \\
\hline DBP dipping (\%) & $8.7 \pm 9.0$ & $9.7 \pm 9.0$ & $10.9 \pm 9.5$ & NS & $10.2 \pm 9.2$ & NS \\
\hline \multicolumn{7}{|l|}{ Echocardiographic profile } \\
\hline Septal thickness (mm) & $9.2 \pm 1.1$ & $10.4 \pm 1.8$ & $10.0 \pm 1.7$ & 0.007 & $10.3 \pm 1.8$ & $<0.001$ \\
\hline Wall thickness (mm) & $8.7 \pm 1.1$ & $10.2 \pm 3.6$ & $9.6 \pm 1.6$ & NS & $10.0 \pm 3.1$ & $<0.001$ \\
\hline LV mass (g) & $170.1 \pm 48.0$ & $213.3 \pm 95.1$ & $201.4 \pm 68.9$ & NS & $209.3 \pm 87.1$ & 0.003 \\
\hline LV mass index $\left(\mathrm{g} / \mathrm{m}^{2}\right)$ & $100.3 \pm 25.7$ & $120.1 \pm 57.0$ & $111.7 \pm 31.7$ & NS & $117.3 \pm 50.0$ & 0.017 \\
\hline
\end{tabular}

Italic values are significant $(p<0.05)$

$B M I$ body mass index, $L V H$ left ventricular hypertrophy, $A C E I / D$ angiotensin-converting enzyme insertion/deletion polymorphism, $D B P$ diastolic blood pressure, $S B P$ systolic blood pressure, $L V$ left ventricle, NS non-significant $(p>0.05)$

a Information about II genotype

b Information about ID genotype

c Information about DD genotype

d Information about DD + ID genotypes

$\mathrm{a} \times \mathrm{b} \times \mathrm{c}$ Statistical analysis among the groups

$\mathrm{a} \times \mathrm{d}$ Statistical analysis between II genotype and sum of ID + DD genotypes

fact, studies performed in several countries have confirmed this association [22, 28-30]. In a Japanese population, one study found higher systolic BP in subjects aged $\geq 50$ years with the ID genotype compared to II carriers, and higher diastolic BP in individuals with the ID and DD genotypes compared to those with the II genotype [25]. Among the possible explanations for these differences, is that BP increases with age, which may have influenced the polymorphism studied [42].

In the current study, an association was found between the D allele and higher systolic BP during wakefulness and during 24-h ABPM in treated patients, results that are not supported by some other authors $[21,23,41]$. On the other hand, higher BP levels were demonstrated for 
Table 4 Logistic regression model for left ventricular hypertrophy according to the genotypes of the ACE I/D

\begin{tabular}{lllll}
\hline Variable & $\beta$ & $\begin{array}{l}\text { Standard } \\
\text { error }\end{array}$ & $\begin{array}{l}\text { Odds ratio (95\% } \\
\text { CI) }\end{array}$ & $\boldsymbol{p}$ value \\
\hline LVH (II as reference) & & & 1.00 & \\
ID & 1.239 & 0.660 & $3.45(0.95-12.59)$ & NS \\
DD & 1.757 & 0.690 & $5.80(1.50-22.44)$ & 0.011 \\
LVH (II as reference) & & & 1.00 & \\
DD + ID & 1.419 & 0.645 & $4.14(1.17-14.65)$ & 0.028 \\
\hline
\end{tabular}

Italic values are significant $(p<0.05)$

$A C E$ I/D angiotensin-converting enzyme insertion/deletion polymorphism, $L V H$ left ventricular hypertrophy, NS non-significant $(p>0.05) p<0.05$ significant

all evaluated periods (wake, sleep and 24-h) in elderly hypertensive Japanese patients who had the D allele [43]. In addition, Julve et al. [44] reported slightly higher BP levels in patients with the DD genotype, due to higher $\mathrm{BP}$ during the nighttime and thus less nocturnal dipping. Although some authors demonstrated this association only in males [22, 45], the authors of a meta-analysis found $79 \%$ greater risk of hypertension in females with the DD compared to those with the II genotype [13].

In the present study, the ACE I/D polymorphism had no influence on ND, which corroborates the results of other authors [21,23] although one study demonstrated a smaller drop between awake and sleep BP in hypertensive patients with the DD genotype in comparison to carriers of the I allele [44]. In addition, there was no effect of ACE I/D polymorphism or serum ACE levels on circadian variability of blood pressures among pediatric renal transplant patients [46] and in patients with type 1 diabetes [47].

In relation to the association between the $\mathrm{ACE} I / D$ polymorphism and TOD in hypertensive individuals, the current research shows that individuals with the DD genotype had an almost fivefold higher risk for LVH compared to those with the II genotype, a condition reported by previous studies $[10,11]$. Recently, two meta-analyses demonstrated an association between the ACE I/D polymorphism and LVH $[20,48]$. However, other authors did not confirm this association $[49,50]$. These conflicting results may reflect the influence of ethnicity, comorbidities, and even of antihypertensive treatment on the ACE I/D polymorphism and TOD associated with HT.

There is evidence that hypertensive patients with the DD genotype present the best antihypertensive response to medications, especially in respect to renin-angiotensin system (RAS) blockers [51, 52]. These studies demonstrated a genetic influence on response to BP treatment, and the effect of RAS blockers on the regression of LVH. Recently, another investigation demonstrated individuals presented with emergency hypertensive (HE) characterized by TOD had a lower frequency of the II genotype and less use of RAS blockers when compared with the hypertensive urgency group, characterized as no TOD. Thus, the risk of an individual having HE was increased in the presence of these two conditions (low frequency of the II genotype and less use of RAS blockers) [18]. On the other hand, one study demonstrated the effect of ramipril in inflammatory response in patients undergoing coronary artery bypass grafts without the ACE I/D gene polymorphism influence [53].

It is known that TOD is more related to the mean 24-h BP levels than office BP levels [1, 2], which highlights the need for ABPM to evaluate hypertensive patients. The absence of ND seems to correlate with TOD in hypertensive individuals [54], although this result was not found in the current study.

In the present study, the DD genotype was associated to higher risk of LVH compared to the II genotype, which suggests that the ACE I/D polymorphism may be more important than ND in the genesis of LVH. In favor of this hypothesis, the results of a meta-analysis found a greater risk for $\mathrm{LVH}$ associated with the D allele or DD genotype in untreated hypertensive patients [20]. In addition, DD genotype was also independently associated with worse echocardiographic outcome in patients with non-ischemic heart failure [55]. This is related to an increased neurohormonal response, mainly of the reninangiotensin aldosterone system [56]. So, it is important to point that LVH is an early TOD associated to cardiac insufficiency. These facts suggest that independent of the treatment, LVH occurs more frequently in individuals with the D allele or DD genotype. Thus, it is important to highlight that it is possible to detect the impact of genetic load on the cardiac phenotype, even with pharmacological treatment.

Some limitations of this study should be mentioned. First, the size of the sample was small, in part, because of the difficulty to select patients due to the exclusion criteria. Second, it was not possible to exclude patients with obstructive sleep apnea, a fact that may influence the frequency of LVH. However, we have excluded patients with $\mathrm{BMI} \geq 35 \mathrm{~kg} / \mathrm{m}^{2}$, which reduces greatly the possibility of sleep apnea. Finally, the lack of a control group of normotensive individuals, in our viewpoint, was the main limitation of this study. Besides, we can cite two strong points. The study population was separated in two groups, according to nocturnal dipping and the investigation of influence of the ACE I/D polymorphism on 24-h BP levels and on target organ damage.

\section{Conclusions}

To our knowledge, this is the first study that evaluates the ACE I/D polymorphism in respect to ABPM and 
TOD in Brazilian hypertensive patients. The present study reports two findings: the presence of the $\mathrm{D}$ allele of the ACE I/D polymorphism is correlated with higher mean 24-h systolic BP and wake systolic BP, and the DD genotype is associated with higher prevalence of $\mathrm{LVH}$ in non-diabetic hypertensive patients on antihypertensive treatment.

\begin{abstract}
Abbreviations
HT: hypertension; TOD: target organ damage; LV: left ventricular; LVH: left ventricular hypertrophy; BP: blood pressure; ND: nocturnal blood pressure dipping; ACE: angiotensin-converting enzyme; I/D: insertion/deletion; DM: diabetes mellitus; BMl: body mass index; MI: myocardial infarction; DLP: dyslipidemia; TC: total cholesterol; HDL-c: high-density lipoprotein cholesterol; LDL-c: low-density lipoprotein cholesterol fraction; TG: triglycerides; LVMI: left ventricular mass index; ABPM: ambulatory blood pressure monitoring; PCR: polymerase chain reaction; OR: odds ratio; Cl: confidence interval; RAS: reninangiotensin system.
\end{abstract}

\section{Authors' contributions}

Conceived and designed the experiments: JFVM. Performed the experiments: LNCM, ROVM, LRP, MASP, DRSS, JFVM. Analyzed the data: LNCM, ROVM, JFVM. Contributed reagents/materials/analysis tools: CBC, JCYT, JPC, MASP, DRSS, JFVM. Wrote the paper: LNCM, ROVM, JFVM. All authors read and approved the final manuscript.

\section{Author details \\ ${ }^{1}$ Hypertension Clinic, Internal Medicine Department, State Medical School in São José do Rio Preto (FAMERP) and Hospital de Base, Ave Brig. Faria Lima 5416, São José do Rio Preto, São Paulo 15090-000, Brazil. ${ }^{2}$ Molecular Biology Department, FAMERP, São Paulo, Brazil.}

\section{Acknowledgements}

We thank the reviewer David Hewitt for correcting both spelling and grammar of the English text.

\section{Compliance with ethical guidelines}

\section{Competing interests}

The authors declare that they have no competing interests.

Received: 25 March 2015 Accepted: 20 August 2015

Published online: 04 September 2015

\section{References}

1. Clement DL, De Buyzere ML, De Bacquer DA, de Leeuw PW, Duprez D, Fagard $\mathrm{RH}$, et al. Office versus Ambulatory Pressure Study Investigators. Prognostic value of ambulatory blood-pressure recordings in patients with treated hypertension. N Eng J Med. 2003;348:2407-15.

2. Dolan E, Stanton A, Thijs L, Hinedi K, Atkins N, McClory S, et al. Superiority of ambulatory over clinic blood pressure measurement in predicting mortality: the Dublin outcome study. Hypertension. 2005;46:156-61.

3. Brotman DJ, Davidson MB, Boumitri M, Vidt DG. Impaired diurnal blood pressure variation and all-cause mortality. Am J Hypertens. 2008;21:92-7.

4. Vaz-de-Melo RO, Toledo JC, Loureiro AA, Cipullo JP, Moreno Júnior H, Martin JF. Absence of nocturnal dipping is associated with stroke and myocardium infarction. Arq Bras Cardiol. 2010:94:79-85.

5. Rigat B, Hubert C, Alhenc-Gelas F, Cambien F, Corvol P, Soubrier F. An insertion/deletion polymorphism in the angiotensin l-converting enzyme gene accounting for half the variance of serum enzyme levels. J Clin Invest. 1990;86:1343-6.

6. Zintzaras E, Raman G, Kitsios G, Lau J. Angiotensin-converting enzyme insertion/deletion gene polymorphic variant as a marker of coronary artery disease: a meta-analysis. Arch Intern Med. 2008;168:1077-89.
7. Hamelin BA, Zakrzewski-Jakubiak M, Robitaille NM, Bogaty P, Labbé $L$, Turgeon J. Increased risk of myocardial infarction associated with angiotensin-converting enzyme gene polymorphism is age dependent. J Clin Pharmacol. 2011:51:1286-92.

8. Vaisi-Raygani A, Ghaneialvar H, Rahimi Z, Nomani H, Saidi M, Bahrehmand $F$, et al. The angiotensin-converting enzyme D allele is an independent risk factor for early onset coronary artery disease. Clin Biochem. 2010;43:1189-94.

9. Kato N, Tatara Y, Ohishi M, Takeya Y, Onishi M, Maekawa Y, et al. Angiotensin-converting enzyme single nucleotide polymorphism is a genetic risk factor for cardiovascular disease: a cohort study of hypertensive patients. Hypertens Res. 2011;34:728-34.

10. Perticone F, Ceravolo R, Cosco C, Trapasso M, Zingone A, Malatesta P, et al. Deletion polymorphism of angiotensin-converting enzyme gene and left ventricular hypertrophy in southern Italian patients. J Am Coll Cardiol. 1997;29:365-9.

11. Pontremoli R, Ravera M, Viazzi F, Nicolella C, Berruti V, Leoncini G, et al. Genetic polymorphism of the renin-angiotensin system and organ damage in essential hypertension. Kidney Int. 2000;57:561-9.

12. Fedor R, Asztalos L, Locsey L, Szabó L, Mányiné IS, Fagyas M, et al. Insertion/deletion polymorphism of the angiotensin-converting enzymes predicts left ventricular hypertrophy after renal transplantion. Transplant Proc. 2011:43:1259-60.

13. Staessen JA, Wang JG, Ginocchio G, Petrov V, Saavedra AP, Soubrier $F$, et al. The deletion/insertion polymorphism of the angiotensin converting enzyme gene and cardiovascular-renal risk. J Hypertens. 1997;15:1579-92.

14. Ng DP, Tai BC, Koh D, Tan KW, Chia KS. Angiotensin-I converting enzyme insertion/deletion polymorphism and its association with diabetic nephropathy: a meta-analysis of studies reported between 1994 and 2004 and comprising 14,727 subjects. Diabetologia. 2005;48:1008-16.

15. Foffa I, Murzi M, Mariani M, Mazzone AM, Glauber M, Ait Ali L, Andreassi $M G$, et al. Angiotensin-converting enzyme insertion/deletion polymorphism is a risk factor for thoracic aortic aneurysm in patients with bicuspid or tricuspid aortic valves. J Thorac Cardiovasc Surg. 2012;144:390-5.

16. Chen Z, Xu F, Wei Y, Liu F, Qi H. Angiotensin converting enzyme insertion/ deletion polymorphism and risk of pregnancy hypertensive disorders: a meta-analysis. J Renin Angiotensin Aldosterone Syst. 2012;13:184-95.

17. Reshetnikov EA, Akulova LY, Dobrodomova IS, Dvornyk VY, Polonikov AV, Churnosov MI. The insertion-deletion polymorphism of the ACE gene is associated with increased blood pressure in women at the end of pregnancy. J Renin Angiotensin Aldosterone Syst. 2013. doi:10.1177/1470320313501217.

18. Vilela-Martin JF, Vaz-de-Melo RO, Cosenso-Martin LN, Kuniyoshi CH, Yugar-Toledo JC, Pinhel MA, et al. Renin angiotensin system blockage associates with insertion/deletion polymorphism of angiotensin-converting enzyme in patients with hypertensive emergency. DNA Cell Biol. 2013;32:1-8.

19. Li Y, Yang P, Wu S, Yuan J, Shen C, Wu Y, et al. Gender-specific association between ACE gene I/D polymorphism and blood pressure response to hydrochlorothiazide in Han Chinese hypertensive patients. Biochem Genet. 2011:49:704-14.

20. Li X, LiY, Jia N, Guo S, Chu S, Niu W. Angiotensin-converting enzyme gene deletion allele increases the risk of ventricular hypertrophy: evidence from a meta-analysis. Mol Biol Rep. 2012;39:10063-75.

21. Maeda Y, Ikeda U, Ebata H, Hojo Y, Seino Y, Nakagami H, et al. Angiotensin converting enzyme gene polymorphism in essential hypertension based on ambulatory blood pressure monitoring. Am J Hypertens. 1997;10:786-9.

22. O'Donnell CJ, Lindpaintner K, Larson MG, Rao VS, Ordovas JM, Schaefer EJ, et al. Evidence for association and genetic linkage of the angiotensinconverting enzyme locus with hypertension and blood pressure in men but not women in the Framingham Heart Study. Circulation. 1998;97:1766-72

23. Matsubara M, Suzuki M, Fujiwara T, Kikuya M, Metoki H, Michimata M, et al. Angiotensin-converting enzyme I/D polymorphism and hypertension: the Ohasama study. J Hypertens. 2002;20:1121-6.

24. Staessen JA, Wang JG, Brand E, Barlassina C, Birkenhäger WH, Herrmann SM, et al. Effects of three candidate genes on prevalence and incidence of hypertension in a Caucasian population. J Hypertens. 2001;19:1349-58. 
25. Todoroki M, Minami J, Ishimitsu T, Ohrui M, Matsuoka H. Relation between the angiotensin-converting enzyme insertion/deletion polymorphism and blood pressure in Japanese male subjects. J Hum Hypertens. 2003;17:713-8.

26. Mondry A, Loh M, Liu P, Zhu AL, Nagel M. Polymorphisms of the insertion/ deletion ACE and M235T AGT genes and hypertension: surprising new findings and meta-analysis of data. BMC Nephrol. 2005;6:1.

27. Freitas SR, Cabello PH, Moura-Neto RS, Dolinsky LC, Lima AB, Barros M, et al. Analysis of renin-angiotensin-aldosterone system gene polymorphisms in resistant hypertension. Braz J Med Biol Res. 2007;40:309-16.

28. Ramachandran V, Ismail P, Stanslas J, Shamsudin N, Moin S, Mohd Jas R. Association of insertion/deletion polymorphism of angiotensin-converting enzyme gene with essential hypertension and type 2 diabetes mellitus in Malaysian subjects. J Renin Angiotensin Aldosterone Syst. 2008;9:208-14.

29. Bautista LE, Vargas Cl, Oróstegui M, Gamarra G. Population-based casecontrol study of renin-angiotensin system genes polymorphisms and hypertension among Hispanics. Hypertens Res. 2008;31:401-8.

30. Niu W, Qi Y, Hou S, Zhai X, Zhou W, Qiu C. Haplotype-based association of the renin-angiotensin-aldosterone system genes polymorphisms with essential hypertension among Han Chinese: the Fangshan study. J Hypertens. 2009;27:1384-91.

31. Jiang X, Sheng H, Li J, Xun P, Cheng Y, Huang J, et al. Association between renin-angiotensin system gene polymorphism and essential hypertension: a community-based study. J Hum Hypertens. 2009;23:176-81.

32. American Diabetes Association. Diagnosis and classification of diabetes mellitus. Diabetes Care. 2004;27(Suppl. 1):S5-10.

33. Atherosclerosis Department of Brazilian Society of Cardiology. Brazilian Guidelines for Dyslipidemia. Arq Bras Cardiol. 2004;88(Suppl 1):2-19.

34. Friedewald WT, Levy RI, Fredrickson DS. Estimation of the concentration of low-density lipoprotein cholesterol in plasma, without use of the preparative ultracentrifuge. Clin Chem. 1972;18:499-502.

35. Lang RM, Bierig M, Devereux RB, Flachskampf FA, Foster E, Pellikka PA, et al. Recommendations for chamber quantification: a report from the American Society of Echocardiography's Guidelines and Standards Committee and the Chamber Quantification Writing Group, developed in conjunction with the European Association of Echocardiography, a branch of the European Society of Cardiology. J Am Soc Echocardiogr. 2005;18:1440-63.

36. Ganau A, Devereux RB, Roman MJ, de Simone G, Pickering TG, Saba PS, et al. Patterns of left ventricular hypertrophy and geometric remodeling in essential hypertension. J Am Coll Cardiol. 1992;19:1550-8.

37. Mor-Avi V, Lang RM, Badano LP, Belohlavek M, Cardim NM, Derumeaux G, et al. Current and evolving echocardiographic techniques for the quantitative evaluation of cardiac mechanics: ASE/EAE consensus statement on methodology and indications endorsed by the Japanese Society of Echocardiography. Eur J Echocardiogr. 2011;12:167-205.

38. Information on V Brazilian Guidelines on Ambulatorial Blood Pressure Monitoring (ABPM V) e III Brazilian Guidelines on Home Blood Pressure Monitoring (HBPM III). Brazilian Society of Cardiology, Brazilian Society of Hypertension and Nephrology. 2011. http://publicacoes.cardiol.br/ consenso/2011/diretriz_mapa_mrpa.pdf Accessed 10 Dec 2014

39. Salazar LA, Hirata MH, Cavalli SA, Machado MO, Hirata RD. Optimized procedure for DNA isolation from fresh and cryopreserved clotted human blood useful in clinical molecular testing. Clin Chem. 1998;44(8 Pt1):1748-50

40. O'Dell SD, Humphries SE, Day IN. Rapid methods for population-scale analysis for gene polymorphisms: the ACE gene as an example. Br Heart J. 1995;73:368-71.

41. Castellano M, Glorioso N, Cusi D, Sarzani R, Fabris B, Opocher G, et al. Genetic polymorphism of the renin-angiotensin-aldosterone system and arterial hypertension in the Italian population: the GENIPER Project. J Hypertens. 2003;21:1853-60.

42. Kotchen JM, McKean HE, Kotchen TA. Blood pressure trends with aging. Hypertension. 1982;4(5 Pt 2):III128-34.

43. Kario K, Hoshide S, Umeda Y, Sato Y, Ikeda U, Nishiuma S, et al. Angiotensinogen and angiotensin-converting enzyme genotypes, and day and night blood pressures in elderly Japanese hypertensives. Hypertens Res. 1999;22:95-103.

44. Julve R, Chaves FJ, Rovira E, Pascual JM, Miralles A, Armengodd ME, et al. Polymorphism insertion/deletion of the ACE gene and ambulatory blood pressure circadian variability in essential hypertension. Blood Press Monit. 2001;6:27-32.

45. Higaki J, Baba S, Katsuya T, Sato N, Ishikawa K, Mannami T, et al. Deletion allele of angiotensin-converting enzyme gene increases risk of essential hypertension in Japanese men: the Suita Study. Circulation. 2000;101:2060-5.

46. Serdaroglu E, Mir S, Berdeli A. Hypertension and ace gene insertion/ deletion polymorphism in pediatric renal transplant patients. Pediatr Transplant. 2005;9:612-7.

47. Deja G, Borowiec M, Fendler W, Pietrzak I, Szadkowska A, Machnica L, et al. Non-dipping and arterial hypertension depend on clinical factors rather than on genetic variability of ACE and RGS2 genes in patients with type 1 diabetes. Acta Diabetol. 2014;51:633-40.

48. Jin Y, Kuznetsova T, Thijs L, Richart T, Stolarz-Skrzypek K, Liu Yanping, et al. Association of echocardiographic left ventricular structure with the ACE D/I polymorphism: a meta-analysis. J Renin Angiotensin Aldosterone Syst. 2011;12:243-53.

49. Gomez-Angelats E, de la Sierra A, Enjuto M, Sierra C, Oriola J, Francino A, et al. Lack of association between ACE gene polymorphism and left ventricular hypertrophy in essential hypertension. J Hum Hypertens. 2000;14:47-9.

50. Wu S, Hong J, Li H, Feng S, Qiao D, Gao M, et al. No correlation of polymorphism of angiotensin-converting enzyme genes with left ventricular hypertrophy in essential hypertension. Hypertens Res. 2000;23:261-4.

51. Hernández D, Lacalzada J, Salido E, Linares J, Barragán A, Lorenzo V, et al. Regression of left ventricular hypertrophy by lisinopril after renal transplantation: role of ACE gene polymorphism. Kidney Int. 2000;58:889-97.

52. Nakayama M, Nakano H, Tsuboi N, Kurosawa T, Tsuruta Y, Iwasaki Y, et al. The effect of angiotensin receptor blockade ARB on the regression of left ventricular hypertrophy in hemodialysis patients: comparison between patients with D allele and non-D allele ACE gene polymorphism. Clin Nephrol. 2005;64:358-63.

53. KüçüK MU, Sucu N, Firat SS, Aytaçoglu BN, Vezir Ö, Bozali C, et al. Role of ACE I/D gene polymorphisms on the effect of ramipril in inflammatory response and myocardial injury in patients undergoing coronary artery bypass grafts. Eur J Clin Pharmacol. 2014;70:1443-51.

54. Torun D, Sezer S, Arat Z, Pelit A, Yigit F, Ozdemir FN, et al. The frequency of combined target organ damage and the beneficial effect of ambulatory blood pressure monitoring in never treated mild-to-moderate hypertensive patients. Int Heart J. 2005;46:1073-82.

55. Albuquerque FN, Brandão AA, Silva DA, Mourilhe-Rocha R, Duque GS, Gondar AFP, et al. Angiotensin-converting enzyme genetic polymorphism: its impact on cardiac remodeling. Arq Bras Cardiol. 2014;102:70-9.

56. Huang W, Xie C, Zhou H, Yang T, Sun M. Association of the angiotensinconverting enzyme gene polymorphism with chronic heart failure in Chinese Han Patients. Eur J Heart Fail. 2004;6:23-7.

\section{Submit your next manuscript to BioMed Central and take full advantage of:}

- Convenient online submission

- Thorough peer review

- No space constraints or color figure charges

- Immediate publication on acceptance

- Inclusion in PubMed, CAS, Scopus and Google Scholar

- Research which is freely available for redistribution

Submit your manuscript at

www.biomedcentral.com/submit

C BioMed Central 